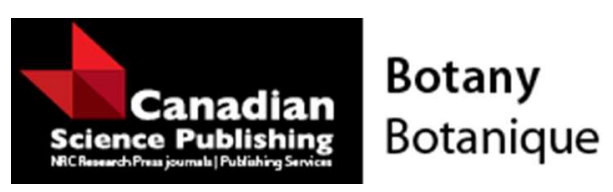

\title{
Staminal wing and a novel secretory structure of asclepiads
}

\begin{tabular}{|r|l|}
\hline Journal: & Botany \\
\hline Manuscript ID & cjb-2016-0239.R2 \\
\hline Manuscript Type: & Article \\
\hline Date Submitted by the Author: & 23-Feb-2017 \\
\hline Complete List of Authors: & Demarco, Diego; Universidade de São Paulo, Botânica \\
\hline Keyword: & Asclepiads, flower development, guide rail, secretion, androecium \\
\hline \multicolumn{2}{|l}{} \\
\hline
\end{tabular}

\section{SCHOLARONE $^{\text {M }}$}

Manuscripts 


\section{Staminal wing and a novel secretory structure of asclepiads}

Diego Demarco

Departamento de Botânica, Instituto de Biociências, Universidade de São Paulo, 05508-090, São Paulo - SP, Brazil

Email: diegodemarco@,usp.br 


\begin{abstract}
Asclepiads (Asclepiadoideae, Apocynaceae) have morphologically complex flowers with a wide range of secretory structures related to their defense and pollination. A striking feature of the flowers is the presence of a guide rail formed by staminal wings, which is related to the guidance of the pollinator to the pollinarium translator and the retention of the pollinium. Previous analyses of floral ontogeny in asclepiads detected the presence of a possible gland on the staminal wing during flower development. The goal of the present study was to verify the occurrence of a secretory structure on the staminal wing and its possible function through ontogenetic and histochemical analyses of the presumed gland. Staminal wings are formed early in developing flowers, and a gland is originated in the outer and inner margins of the guide rail in all species. This gland releases a secretion composed of mucilage and lipids, which likely assists in the introduction of the pollinator appendage into the narrow guide rail by lubricating the staminal wings. The gland degenerates before anthesis, increasing the space within the guide rail and enabling the introduction of the pollinarium. This new secretory structure may be present in floral buds of all asclepiads.
\end{abstract}

Key words: Asclepiads, flower development, guide rail, pollination mechanism, secretion, androecium. 


\section{Introduction}

Asclepiadoideae, also known as asclepiads, are one of the three subfamilies of Apocynaceae notable for the extreme complexity of their flowers. Like in the Periplocoideae and Secamonoideae, asclepiads have a number of characteristics, such as guide rail, corona, secretory style head, pollinia and gynostegium, which are unique or with restricted distribution in angiosperms (Fishbein 2001; Livshultz 2010; Rapini 2012; Nazar et al. 2013; Endress 2016; Demarco 2017). In addition, these flowers share an extremely stable merosity and an unusual synorganization of parts through adnation and congenital or postgenital connation which gave rise to new organs (Endress 1994, 2016).

Associated with this structural complexity, these flowers have specific pollination mechanisms with various floral structures related to the guidance of insects during pollination, such as the guide rail, corona, trichomes and the position of nectar holders in the flower (Kunze 1991, 1995, 1996, 1997, 1999; Wiemer et al. 2012; Endress 2016). The guide rail is generally formed by lignified projections of the anthers, which are present in Rauvolfioideae (rarely), Apocynoideae, Secamonoideae and Asclepiadoideae (Fallen 1986; Kunze 1996; Endress and Bruyns 2000). In Asclepiadoideae, the guide rail is usually considered to be formed by the wings of two adjacent anthers, corresponding to the basal elongations of the sterile dorsal pollen sacs (Kunze 1996; Endress and Bruyns 2000; Endress 2016). However, contrary arguments raise doubts about the origin of the wing (Safwat 1962), which should be analyzed with a developmental perspective.

In addition to the structural complexity and diversity of pollination mechanisms, flowers of asclepiads have an extensive secretory apparatus related to flower protection and pollination, such as colleters, glandular trichomes, laticifers, secretory idioblasts, 
nectaries, osmophores, stylar channels, obturators, some regions of the style head and at times portions of the corona (Rao and Ganguli 1963; Kunze 1991, 1997; Valente 1995; Valente and Costa 2005; Demarco and Castro 2008; Wiemer et al. 2012; Demarco $2008,2014,2015,2017)$. However, the vast majority of the studies that investigated the floral structure in this group analyzed only the adult flower but did not observe the flower development. The lack of indepth studies in the intermediate stages of the floral organ formation generates a loss of important information to understand the function of the floral secretory apparatus because each secretory structure starts its activity in a specific time of flower ontogeny and this secretory period is directly related to its function (Demarco 2008).

Previous ontogenetic analyses of asclepiad flowers detected the possible presence of a secretory structure in the guide rail of various species (pers. obs.), which has never been described. It is formed during the floral bud development and degenerates before anthesis. The goal of this study was to verify the occurrence of glands in the guide rail and their possible role in the pollination of asclepiads through ontogenetic and structural investigation of the staminal wings, in addition to a histochemical analysis of their secretion in five genera of Asclepiadeae (Asclepiadoideae).

\section{Material and methods}

Several inflorescences from Asclepias curassavica L. (subtribe Asclepiadinae), Blepharodon bicuspidatum E. Fourn., Peplonia axillaris (Vell.) Fontella \& Rapini (subtribe Metastelmatinae), Matelea denticulata (Vahl) Fontella \& E.A. Schwarz (subtribe Gonolobinae), and Oxypetalum banksii subsp. banksii Roem. \& Schult. (subtribe Oxypetalinae; Endress et al. 2014) were collected for this study, as described 
in Table 1. Vouchers were incorporated to the Herbarium of the Universidade Estadual de Campinas (UEC).

Floral buds and adult flowers of the five species were fixed in formalin-acetic acid-alcohol (FAA) solution for 24h (Johansen 1940), buffered neutral formalin (BNF) in $0.1 \mathrm{M}$ sodium phosphate buffer ( $\mathrm{pH} 7.0$; Lillie 1965), or ferrous sulfate-formalin solution (FSF; Johansen 1940) for 48 h, being subsequently stored in ethanol 70\%.

For micromorphological analysis, flowers fixed in FAA were isolated, dehydrated in ethanol series, critical point dried, mounted on stubs and sputter-coated with gold. The observations and recording of images were performed using a scanning electron microscope (Jeol JSM 5800 LV, Tokyo, Japan).

Seven developmental stages were selected for the ontogenetic study of the staminal wing based on the morphological changes observed during the flowers development, avoiding possible discrepancies caused by the different sizes of flowers among species: 1) floral meristem; 2) primordia of petals, stamens, and carpels completely wrapped by the calyx; 3) beginning of corolla elongation; 4) buds with half the final length; 5) pre-anthesis; 6) anthesis; 7) post-anthesis. Thirty floral buds and flowers of each species were isolated, dehydrated in a butyl series (Johansen 1940), embedded in Paraplast, and transversely and longitudinally sectioned with a 10-12 $\mu \mathrm{m}$ thickness using a rotary microtome (Microm HM340E, Walldorf, Germany). The sections were stained with astra blue and safranin (Gerlach 1984), and the slides were mounted in Permount (Fisher Scientific, Pittsburgh, USA).

For the histochemical study, the following treatments were performed to identify the constituents of the wing gland secretion: ruthenium red for acidic mucilage (Gregory and Baas 1989), tannic acid and ferric chloride for mucilage (Pizzolato 1977), PAS reaction (periodic acid-Schiff) for polysaccharides (Jensen 1962), Sudan black B and 
Sudan IV for lipids (Pearse 1985), Nile blue for acidic and neutral lipids (Cain 1947), copper acetate and rubeanic acid for fatty acids (Ganter and Jollés 1969, 1970), ferric chloride for phenolic compounds (Johansen 1940), Dragendorff's (Svendsen and Verpoorte 1983) and Wagner's reagents (Furr and Mahlberg 1981) for alkaloids. The slides were mounted with glycerin gelatin.

The control for the tests of lipophilic substances were carried out using floral buds previously kept in a solution consisting of methanol, chloroform, water, and hydrochloric acid (High 1984) for $48 \mathrm{~h}$ at room temperature. The control for hydrophilic substances was performed according to the respective techniques. All photomicrographs were taken using an Olympus BX51 microscope (Melville, USA).

\section{Results}

\section{Morphology of the flowers}

The flowers of all studied species have five stamens with prominent staminal corona on the dorsal face (Figs. $1 a$ and 2). The filaments are united, forming the filament tube (Figs. 1b, $2 a$ and $2 d$ ) and each stamen has two lateral projections, called wings, which form the guide rail in front of the stigmatic chamber and alternate with the anthers (Figs. 1c-e, 2, and 3).

\section{Ontogeny of the staminal wings}

Staminal wings originate early in the formation of stamens (Figs. 3a-3f) when the anthers are expanding and the calyx is still closed, wrapping the developing reproductive whorls. They are formed in large part by the tissues of the anther margins in a dorso-lateral position (Figs. $3 a$ and $3 f$ ), while their basal portion is formed by filament tissues (Figs. 3b-3e). In serial sections, it is possible to observe the major extension of the wing at the anther level and its basal portion at the filament level in 
Asclepias, Blepharodon, Peplonia and Oxypetalum (Figs. $3 g$ and $3 h$ ). The wing is formed exclusively by anther tissues only in Matelea (Fig. 3f).

In all species studied, the wings are not vascularized and become lignified in adult flowers (Figs. 2, 4, and 5a-5f). In Asclepias, Blepharodon, Peplonia and Oxypetalum, the wings are long and extend vertically, parallel to the axis of the flower (Figs. $1 a$ and $3 g$ ), while in Matelea they are short and horizontal (Fig. 4i), perpendicular to the axis of the flower.

\section{Structure of the guide rail}

The wings of two adjacent stamens delimit the guide rail (Figs. 3h, 4, and 5), which possesses two distinct chambers (Figs. $4 a$ and $4 b$ ). The outer chamber is located between the secretory portions of staminal wings (or between the outer and inner guide rails) (Figs. $4 a, 4 b, 4 j, 5 a$, and $5 e$ ), where trichomes oriented towards the flower base may be found (Figs. $3 g, 3 h, 4 d, 4 g, 4 h, 4 j, 4 k$, and $5 a-5 e$ ). In contrast, the inner chamber is bound externally by wing glands (or the inner guide rail) and internally by the stigmatic chamber (Figs. $4 a$ and $5 b$ ).

In Asclepias, Matelea and Oxypetalum, the inner chamber of the guide rail is continuous with the stigmatic chamber along almost the entire length and can be distinguished from the latter due to the absence of secretory epidermis (Figs. $4 a$ and $4 j$ ). On the other hand, this chamber is isolated from the stigmatic chamber by protrusions of the stamens in Peplonia (Fig. 5b), and in Blepharodon the guide rail has only one chamber, where the pollinium or part of the pollinarium is inserted (Figs. $3 j$ and $4 d$ ).

The guide rail of all species have a wider aperture at the base, tapering toward the top, but Blepharodon is distinct from the other species by having the widest base. The guide rail of that species is basally continuous with another chamber formed by expansions of the corona in an interstaminal position (Figs. $4 g$ and $4 i$ ). Thus, the 
staminal wing is continuous with the interstaminal corona, forming a long, unique chamber or a guide rail with mixed origin. The origin of each part is easily detectable through serial anatomical sections because the interstaminal corona is not lignified, unlike the staminal wing (Figs. $4 g-4 i$ ).

\section{Structure and histochemistry of the wing gland}

The gland occurs in two regions of the wing: one external on the margin of the wing (outer guide rail) and a second, internal and on a bulge (inner guide rail) formed by the proliferation of the ground meristem (Figs. $4 a, 4 b, 4 d, 4 e, 5 a$, and $5 e$ ). The secretory tissue is present along almost the entire length of the wing (Figs. $4 f$, $4 i$, and $5 f$ ) and is absent only at its upper and lower ends.

Only the uniseriate epidermis which covers a core of ground parenchyma of the wing gland is secretory (Figs. $4 b, 4 d-4 f, 4 i, 5 a$, and $5 e-5 i$ ). The shape of these epidermal secretory cells vary in the outer gland from square, observed in Peplonia (Fig. 5a), to rectangular, observed in Oxypetalum (Fig. 5e). However, they are typically rectangular and arranged in a palisade in the inner gland of all species studied (Figs. $4 b, 4 d-4 f, 5 a$, $5 e$, and $5 f$ ), except Matelea, where they are square (Fig. $4 i$ ). In all secretory cells, the walls are thin, the cytoplasm appears dense (Figs. $4 d-4 f$, $5 e$, and $5 f$ ) with small globules (Figs. $4 e$ and $4 f$ ) and the nucleus occupies a central position in the cell (Fig. 5f). Their secretion is composed of mucilage and lipids (Figs. $5 g-5 i$ and Table 2) and is released within the guide rail, where they remain throughout anthesis. However, the secretion is often removed from this slit during fixation and processing of the samples and may not be observed in the anatomical sections.

\section{Function of the wing gland}

The wing gland begins its secretory activity in the stage 4 and degenerates before pre-anthesis (stage 5) in all species, i.e. in the intermediate stages of development 
of the floral buds (Figs. 4 and 5). The wing gland initially occupies a large volume inside the guide rail but after it degenerates, the gap left behind will allow later the insertion of the pollinium or part of the pollinarium. In mature flowers, the wings of the stamens and the trichomes found inside the slit are completely lignified (Figs. $4 g, 4 h, 4 j$, $4 k, 5 c$, and $5 d$ ), the glands are shrunk, and the outer and inner chambers form a single continuous cavity with the stigmatic chamber in Asclepias (Fig. 4c) and Oxypetalum. In Blepharodon, Peplonia and Matelea, there is a spatial separation of the guide rail and the stigmatic chamber due to a broader protrusion of the inner guide rail (Figs. $4 g, 4 j$, and $5 b)$.

In the top view of the gynostegium, only the outer chamber is exposed at the upper portion of the guide rail because the style head covers the stigmatic chamber and, at times, the inner chamber of the guide rail (Figs. $1 c, 3 g$, and $5 c$ ) and it is not possible to insert the pollinium in this part through the top. In fact, the guide rail directs the pollinator body part and receives the pollinium in the inner chamber of the guide rail or in the stigmatic chamber through its basal aperture, where the pollen germinates (Fig. $3 j)$.

\section{Discussion}

Flowers of asclepiads have several secretory structures involved in pollination and protection strategies (Demarco 2017 and references therein). In the present study, a novel floral gland is described on the staminal wing, and is likely related to the double function of the guide rail: guiding a part of the insect's body toward the corpusculum and receiving the pollinium into the guide rail itself or into the stigmatic chamber.

\section{Staminal wing}

All flowers of Asclepiadoideae possess lignified staminal wings, which are considered basal elongations of the dorsal pollen sacs (Demeter 1922; Endress 1994, 
2016; Kunze 1996; Omlor 1996; Endress and Bruyns 2000; Wiemer et al. 2012). This statement is based on the presence of sterile lignified basal appendages of those pollen sacs in Apocynoideae, Secamonoideae, Asclepiadoideae and in few genera of Rauvolfioideae, and to the presence of bisporangiate anthers in Asclepiadoideae (Endress and Bruyns 2000).

Demeter (1922) considered guide rails modifications of anther margins to have evolved by the transformation of the two dorsal sterile pollen sacs in asclepiads. However, Safwat (1962) opposed this hypothesis, claiming that in Secamone (currently Secamonoideae, sister group of Asclepiadoideae) the four pollen sacs are fertile and the guide rail is also present. After these studies, Kunze (1996) performed an extensive ontogenetic and anatomical study analyzing several genera of Apocynaceae belonging to different subfamilies and interpreted the guide rail again as basal elongations of dorsal pollen sacs, due mainly to the extension of the endothecial tissue into the staminal wings. The present study confirmed that the origin of this structure is exclusively derived from the tissues of the anthers in Matelea. On the other hand, the ontogenetic origin of the staminal wings in flowers of other Asclepiadeae is variable. In Asclepias, Blepharodon, Peplonia and Oxypetalum, they are formed by lateral projections of the anther and filament.

This work also shows that the guide rail may have a mixed origin. In Blepharodon bicuspidatum, the staminal wing is continuous with the interstaminal corona, forming a unique chamber, which assists in the guiding function of the staminal wings and from which the pollinium should be inserted. This finding reinforces the floral synorganization during flower development in this group.

According to Kunze (1996), the presence of lignified tissue in the basal portion of the guide rail originating from the filament indicates that the basal elongations of 
anther are congenitally fused to the filament and/or to the filament tube. However, the reinforcement necessary for the guiding function of the staminal wings may have been an important evolutionary factor for the presence of lignified tissue in these structures, and the developmental analysis shows that the origin of the wing basal part is from the filament tube. Therefore, it is undeniable that the predominant participation of anther in the formation of the guide rail and the basal portion of the wing seems to be influenced by the differentiation of its antheral portion, but to definitively distinguish whether the portion originating from the filament comes from exclusive tissues of this part of the stamen or not will require an analysis of the expression of specific anther genes. Based on these arguments, I propose changing the term "anther wing" to "staminal wing" for asclepiads, avoiding the use of a term which refers to an exclusive origin from a part of the stamen.

\section{Wing gland}

All five species studied, belonging to four subtribes of Asclepiadeae, have glands on the staminal wings. Although several studies have been performed with this group, few have detected a protrusion on the outer and inner guide rail. Kunze (1995) observed them in Matelea reticulata (Engelm.) Woodson and designated these structures as pads. Valente (1995) reported them as "small expansions" in Matelea maritima subsp. ganglinosa (Vell.) Font. In addition, it is possible to observe the presence of the gland in illustrations of other works (e.g. Kunze 1996), although the authors did not describe this structure as being one. The first reference to the possible presence of secretory cells on the staminal wing was made by Valente (1977) in flowers of Oxypetalum banksii.

Guide rails of four out of the five species studied are divided into two chambers: an outer chamber, located between the wing glands (or between the outer and inner 
guide rails), and the inner chamber, located between the stigmatic chamber and the inner guide rail. The outer chamber has lignified trichomes directed towards the base of the flower, which also occur in several other genera (Konta et al. 1986; Kunze 1991, 1996; Wiemer et al. 2012). This orientation of the trichomes within the inner guide rail helps prevent a downward movement of the inserted caudicle (Wiemer et al. 2012). Simple, undivided guide rails, as observed in Blepharodon, have been interpreted as a plesiomorphic character due to their presence in Secamone or as an adaptation to the type of insertion of pollinium (Kunze 1991).

According to Kunze $(1991,1996)$, the chamber with lignified trichomes is where the proboscis of the insect arrives, and the chamber without trichomes receives the pollinium. When the proboscis is inserted into the guide rail after collecting nectar, the insect can only remove it if it makes a forward and upward movement due to the lignified trichomes directed toward the base of the flower. Thus, the proboscis contacts the corpusculum adhering to it, and the pollinium brought by the pollinator is retained within the guide rail or within the stigmatic chamber by breaking the translator. The translator rupture is due to the narrowing of the guide rail upward associated with the presence of lignified trichomes or to an inwardly curved striated surface of the staminal wing (Kunze 1991; Liede 1994; Wiemer et al. 2012; Endress 2016).

In addition to the morphology of the guide rail, the shape and composition of the translator aid in the release of pollinium from the pollinator. The rupture of the translator occurs in the caudicle due to its chemical composition distinct from the corpusculum, which makes it more fragile (Demarco 2014). Furthermore, the terminal thickening of some caudicles seems to function as a guiding structure since the pollinium insertion occurs only after the thickened part is caught at the inner guide rail entrance (Wiemer et al. 2012). 
In conclusion, the present study demonstrates that the glands of the staminal wing have their origin, secretory phase and senescence during intermediate stages of development of the floral buds. It also suggests that, based on the location of these glands and the viscous nature of the secretion, it is highly possible that the secretion released within the slit, at times full of lignified trichomes, might serve as a lubricant, facilitating the entrance of a part of the insect's body and/or assisting in the removal of pollinarium adhered to the insect. The disintegration of the gland before anthesis increases the area of the guide rail, which is very narrow, allowing the introduction of the proboscis and/or pollinium into it.

The function assigned to the wing gland and its presence in different subtribes of Asclepiadeae suggests that it may be present in floral buds of all asclepiads (Asclepiadoideae) or, at least, all Asclepiadeae.

\section{Acknowledgements}

I thank FAPESP (proc. no. 02/11881-3; 04/09729-4; Biota/FAPESP proc. no. 03/12595-7) for financial support. This work was carried out during my doctoral studies in the Programa de Pós-Graduação em Biologia Vegetal, Instituto de Biologia, Universidade Estadual de Campinas.

\section{References}

Cain, A.J. 1947. The use of Nile Blue in the examination of lipids. Q. J. Microsc. Sci. 88: $383-392$.

Demarco, D. 2008. Glândulas de órgãos vegetativos aéreos e florais de espécies de Asclepiadoideae (R.Br.) Duby (Asclepiadoideae, Apocynaceae) de mata atlântica do estado de São Paulo. Doctoral thesis, Universidade Estadual de Campinas, Campinas, Brazil. 
Demarco, D. 2014. Secretory tissues and the morphogenesis and histochemistry of pollinarium in flowers of Asclepiadeae (Apocynaceae). Int. J. Plant Sci. 175: 1042-1053. doi:10.1086/677947

Demarco, D. 2015. Micromorfología y histoquímica de los laticíferos de órganos vegetativos de espécies de Asclepiadoideae (Apocynaceae). Acta Biol. Colomb. 20: 57-65. doi: http://dx.doi.org/10.15446/abc.v20n1.42375

Demarco, D. 2017. Floral glands in asclepiads: structure, diversity and evolution. Acta Bot. Bras. 31: in press.

Demarco, D., and Castro, M.M. 2008. Laticíferos articulados anastomosados em espécies de Asclepiadeae (Asclepiadoideae, Apocynaceae) e suas implicações ecológicas. Rev. Bras. Bot. 31: 699-711. doi: http://dx.doi.org/10.1590/S0100$\underline{84042008000400015}$

Demeter, K. 1922. Vergleichende Asclepiadeenstudien. Flora 15: 130-176.

Endress, P.K. 1994. Diversity and evolutionary biology of tropical flowers. Cambridge University Press, Cambridge, UK.

Endress, P.K. 2016. Development and evolution of extreme synorganization in angiosperm flowers and diversity: a comparison of Apocynaceae and Orchidaceae. Ann. Bot. 117: 749-767. doi: 10.1093/aob/mcv119

Endress, M.E., and Bruyns, P.V. 2000. A revised classification of Apocynaceae s.l. Bot. Rev. 66: 1-56. doi: 10.1007/BF02857781

Endress, M.E., Liede-Schumman, S., and Meve, U. 2014. An updated classification for Apocynaceae. $\quad$ Phytotaxa 159: 175-194. doi: http://dx.doi.org/10.11646/phytotaxa.159.3.2

Fallen, M.E. 1986. Floral structure in the Apocynaceae: morphological, functional and evolutionary aspects. Bot. Jahrb. Syst. 106: 245-286. 
Fishbein, M. 2001. Evolutionary innovation and diversification in the flowers of Asclepiadaceae. Ann. Mo. Bot. Gard. 88: 603-623. Available from http://www.jstor.org/stable/3298636

Furr, M., and Mahlberg, P.G. 1981. Histochemical analyses of laticifers and glandular trichomes in Cannabis sativa. J. Nat. Prod. 44: 153-159. doi: $10.1021 / \mathrm{np} 50014 \mathrm{a} 002$

Ganter, P., and Jollés, G. 1969. Histochimie normale et pathologique. Vol. 1. GauthierVillars, Paris, France.

Ganter, P., and Jollés, G. 1970. Histochimie normale et pathologique. Vol. 2. GauthierVillars, Paris, France.

Gerlach, D. 1984. Botanische Mikrotechnik: eine Einführung. $3^{\text {rd }}$ ed. Georg Thieme, Stuttgart, Germany.

Gregory, M., and Baas, P. 1989. A survey of mucilage cells in vegetative organs of the dicotyledons. Isr. J. Bot. 38: 125-174.

High, O.B. 1984. Lipid histochemistry. Oxford University Press, Oxford, UK.

Jensen, W.A. 1962. Botanical histochemistry: principles and practice. WH Freeman \& Co., San Francisco, USA.

Johansen, D.A. 1940. Plant microtechnique. McGraw-Hill, New York, USA.

Konta, F., Suda, T., and Kobayashi, C. 1986. A preliminary study on the floral morphology of Cynanchum (Asclepiadaceae). Acta Phytotax. Geobot. 37: 59-68.

Kunze, H. 1991. Structure and function in asclepiad pollination. Plant Syst. Evol. 176: 227-253. doi: 10.1007/BF00937909

Kunze, H. 1995. Floral morphology of some Gonolobeae (Asclepiadaceae). Bot. Jahrb. Syst. 117: 211-238. 
Kunze, H. 1996. Morphology of the stamen in the Asclepiadaceae and its systematic relevance. Bot. Jahrb. Syst. 118: 547-579.

Kunze, H. 1997. Corona and nectar system in Asclepiadinae (Asclepiadaceae). Flora 192: 175-183.

Kunze, H. 1999. Pollination ecology in two species of Gonolobus (Asclepiadaceae). Flora 194: 309-316.

Liede, S. 1994. Some observations on pollination in Mexican Asclepiadaceae. Madroño 41: 266-276. Available from http://www.jstor.org/stable/41425030

Lillie, R.D. 1965. Histopathologic technic and practical histochemistry. $3^{\text {rd }}$ ed. McGraw-Hill, New York, USA.

Livshultz, T. 2010. The phylogenetic position of milkweeds (Apocynaceae subfamilies Secamonoideae and Asclepiadoideae): evidence from the nucleus and chloroplast. Taxon 59: 1016-1030. doi: 10.2307/20773973

Nazar, N.; Goyder, D.J.; Clarkson, J.J.; Mahmood, T.; Chase, M.W. 2013. The taxonomy and systematics of Apocynaceae: where we stand in 2012. Bot. J. Linn. Soc. 171: 482-490. doi: 10.1111/boj.12005

Omlor, R. 1996. Do Menabea venenata and Secamonopsis madagascariensis represent missing links between Periplocaceae, Secamonoideae and Marsdenieae (Asclepiadaceae)? Kew Bull. 51: 695-715. Available from http://www.jstor.org/stable/4119723

Pearse, A.G.E. 1985. Histochemistry: theoretical and applied. Vol. 2. $4^{\text {th }}$ ed. C. Livingstone, Edinburgh, UK.

Pizzolato, T.D. 1977. Staining of Tilia mucilages with Mayer's tannic acid-ferric chloride. Bull. Torrey Bot. Club 104: 277-279. Available from http://www.jstor.org/stable/2484311 
Rao, V.S., and Ganguli, A. 1963. The floral anatomy of some Asclepiadaceae. Proc. Indian Acad. Sci. (B) 57: 15-44.

Rapini, A. 2012. Taxonomy "under construction": advances in the systematics of Apocynaceae, with emphasis on the Brazilian Asclepiadoideae. Rodriguésia 63: 75-88. doi: http://dx.doi.org/10.1590/S2175-78602012000100007

Safwat, F.M. 1962. The floral morphology of Secamone and the evolution of the pollinating apparatus in Asclepiadaceae. Ann. Mo. Bot. Gard. 49: 95-129. Available from http://www.jstor.org/stable/2394742

Svendsen, A.B., and Verpoorte, R. 1983. Chromatography of alkaloids. Elsevier, New York, USA.

Swarupanandan, K., Mangaly, J.K., Sonny, T.K., Kishorekumar, K., and Chand Basha, S. 1996. The subfamilial and tribal classification of the family Asclepiadaceae. Bot. J. Linn. Soc. 120: 327-369. doi:10.1006/boj1.1996.0018

Valente, M.C. 1977. A flor de Oxypetalum banksii Roem. et Schult. subsp. banksii. Estudo da anatomia e vascularização (Asclepiadaceae). Rodriguésia 29: 161-283. Available from http://www.jstor.org/stable/23492967

Valente, M.C. 1995. Matelea maritima subsp. ganglinosa (Vell.) Font. - Anatomia e vascularização floral (Asclepiadaceae). Arq. Jard. Bot. Rio de Janeiro 33: 75-98.

Valente, M.C., and Costa, C.G. 2005. Estudo anatômico da flor de Marsdenia loniceroides E.Fournier (Asclepiadoideae - Apocynaceae). Rodriguésia 56: 5166. Available from http://www.jstor.org/stable/23498261

Valente, M.C., and Silva, N.M.F. 1984. Anatomia floral de Barjonia erecta (Vell.) Schum. (Asclepiadaceae). Rodriguésia 36: 95-106. Available from http://www.jstor.org/stable/23495099 
Vieira, M.F., and Shepherd, G.J. 2002. Oxypetalum banksii subsp. banksii: a taxon of Asclepiadaceae with an extragynoecial compitum. Plant Syst. Evol. 233: 199206. doi: 10.1007/s00606-002-0204-2

Wiemer, A.P., Sérsic, A.N., Marino, S., Simões, A.O., and Cocucci, A.A. 2012. Functional morphology and wasp pollination of two South American asclepiads (Asclepiadoideae-Apocynaceae). Ann. Bot. 109: 77-93. doi: 10.1093/aob/mcr268 
Table 1. Data on locality, geographical coordinates and vouchers of the species collected for the study.

\begin{tabular}{|c|c|c|c|}
\hline Species & Locality & Coordinates & Collector number \\
\hline Asclepias curassavica L. & Ubatuba-SP & $\begin{array}{l}23^{\circ} 21^{\prime} \mathrm{S} ; \\
44^{\circ} 51^{\prime} \mathrm{W}\end{array}$ & D. Demarco 52, 66, 68 \\
\hline $\begin{array}{l}\text { Blepharodon bicuspidatum } \\
\text { E.Fourn }\end{array}$ & Mogi Guaçu-SP & $\begin{array}{l}22^{\circ} 18^{\prime} \mathrm{S} ; \\
47^{\circ} 20^{\prime} \mathrm{W}\end{array}$ & D. Demarco 7, 11, 14 \\
\hline $\begin{array}{l}\text { Peplonia axillaris (Vell.) } \\
\text { Fontella \& Rapini }\end{array}$ & Ubatuba-SP & $\begin{array}{l}23^{\circ} 21^{\prime} \mathrm{S} ; \\
44^{\circ} 51^{\prime} \mathrm{W}\end{array}$ & D. Demarco 35, 48, 49 \\
\hline $\begin{array}{l}\text { Matelea denticulata (Vahl) } \\
\text { Fontella \& E.A.Schwarz }\end{array}$ & Ubatuba-SP & $\begin{array}{l}23^{\circ} 21^{\prime} \mathrm{S} ; \\
44^{\circ} 51^{\prime} \mathrm{W}\end{array}$ & D. Demarco 37, 38 \\
\hline $\begin{array}{l}\text { Oxypetalum banksii subsp. } \\
\text { banksii Roem. \& Schult. }\end{array}$ & Ubatuba-SP & $\begin{array}{l}23^{\circ} 21^{\prime} \mathrm{S} ; \\
44^{\circ} 51^{\prime} \mathrm{W}\end{array}$ & D. Demarco 57, 70 \\
\hline
\end{tabular}


Table 2. Histochemical tests to identify the major classes of metabolites that comprise the secretion of the wing gland in Asclepiadoideae.

\begin{tabular}{lcc} 
Histochemical test & Substance detected & Wing gland \\
\hline Ruthenium red & acidic mucilage & + \\
Tannic acid and ferric chloride & mucilage & + \\
PAS reaction & carbohydrates & - \\
Ferric chloride & phenolic compounds & - \\
Ferrous sulfate in formalin & phenolic compounds & + \\
Sudan black B & lipids & + \\
Sudan IV & lipids & + \\
Nile blue & acidic lipids & - \\
Cooper acetate and rubeanic acid & fatty acids & - \\
Dragendorff's reagent & alkaloids & - \\
Wagner's reagent & alkaloids &
\end{tabular}

Note. $+=$ present, $-=$ absent 


\section{Legends}

Fig. 1. Scanning electron micrographs of adult flowers of Asclepiadeae. ( $a$ and $c$ ) Blepharodon bicuspidatum. (b and d) Oxypetalum banksii. (e) Asclepias curassavica. (a) Front view of the guide rail and corona with perianth removed. Note the basal aperture of the guide rail through which the pollinarium is inserted. (b) Cross section of the filament tube. $(c)$ Top view of the guide rail with the translator removed. $(d)$ Detail of stigmatic chamber and guide rail. (e) Longitudinal section of the stigmatic chamber and guide rail. $\mathrm{A}$, anther; $\mathrm{Ci}$, interstaminal corona; $\mathrm{Cs}$, staminal corona; $\mathrm{FT}$, filament tube; GR, guide rail; SC, stigmatic chamber; SH, style head; Ws, staminal wing.

Fig. 2. Structure of the flowers of Asclepiadeae. Cross sections. (a) Asclepias curassavica. (b) Blepharodon bicuspidatum. (c) Peplonia axillaris. (d) Oxypetalum banksii. Cs, staminal corona; FT, filament tube; SC, stigmatic chamber; Ws, staminal wing.

Fig. 3. Ontogeny of staminal wing in floral buds of Asclepiadeae. ( $a-e, h$ and $i$ ) Cross sections. ( $f$ and $g$ ) Longitudinal sections. ( $a$ and $b$ ) Asclepias curassavica. (c-e and $g-j$ ) Blepharodon bicuspidatum. (f) Matelea denticulata. ( $a$ and $b$ ) Origin of the staminal wing at anther level $(a)$ and filament level $(b)$. (c-f) Origin of the staminal wing at anther level. Note tissues protruding from the dorsal side of the anther. $(g)$ Longitudinal view of the union between staminal wing and interstaminal corona forming a unique chamber. ( $h$ and $i$ ) Serial sections of the guide rail at staminal wings level $(h)$ and interstaminal corona level $(i)$. $(j)$ Pollinium deposited into stigmatic chamber. Note the germination of pollen inside the chamber. A, anther; $\mathrm{Ci}$, interstaminal corona; FT, filament tube; SC, stigmatic chamber; SH, style head; Ws, staminal wing.

Fig. 4. Structure and senescence of the staminal wing gland in flowers of Asclepiadeae. $(a-e, g, h, j$ and $k$ ) Cross sections. ( $f$ and $i$ ) Longitudinal sections. ( $a, b, d-f$ and $i$ ) Floral 
buds. (c, $g, h, j$ and $k$ ) Adult flowers. (a-c) Asclepias curassavica. (d-h) Blepharodon bicuspidatum. (i-k) Matelea denticulata. ( $a$ and $j$ ) Guide rails with two chambers. $(b)$ Detail of the wing glands in the inner and outer guide rail. (c) Shrunken glands on the lignified staminal wings of an adult flower. $(d)$ Guide rail with only one chamber. $(e, f$ and $i$ ) Details of the secretory epidermis of the wing gland. $(g)$ Presence of shrunken glands and downward-elongated, lignified trichomes in the guide rail. ( $h$ and $k$ ) Polarization microscopy of the staminal wings, evidencing the secondary cell walls of the lignified tissues. Narrow arrow, necrotic wing gland; Wide arrow, secretory epidermis; Gi, inner guide rail; Gic, inner chamber of the guide rail; Go, outer guide rail; Goc, outer chamber of the guide rail; SC, stigmatic chamber; Ws, staminal wing.

Fig. 5. Structure, senescence and histochemistry of the staminal wing gland in flowers of Asclepiadeae. (a-e, g-i) Cross sections. (f) Longitudinal section. (a,e-i) Floral buds. (b-d) Adult flowers. (a-d) Peplonia axillaris. (e, $f$ and $h$ ) Oxypetalum banksii. ( $g$ ) Matelea denticulata. (i) Asclepias curassavica. (a) Staminal wings with the glands on the outer and inner guide rails. ( $b$ and $c$ ) Necrosis of the staminal wing glands. Note the protrusions of the stamens isolating the inner chamber of the guide rail. $(d)$ Polarization microscopy, evidencing the secondary cell walls of the lignified tissues of the entire anther and wings. ( $e$ and $f$ ) Details of the staminal wing glands in transversal and longitudinal view. Note the palisade secretory epidermis. ( $g$ and $h$ ) Mucilage detected by ruthenium red $(g)$ and tannic acid and ferric chloride $(h)$. (i) Lipids detected by Sudan black B. Arrow, necrotic wing gland; Gi, inner guide rail; Gic, inner chamber of the guide rail; Go, outer guide rail; Ws, staminal wing. 

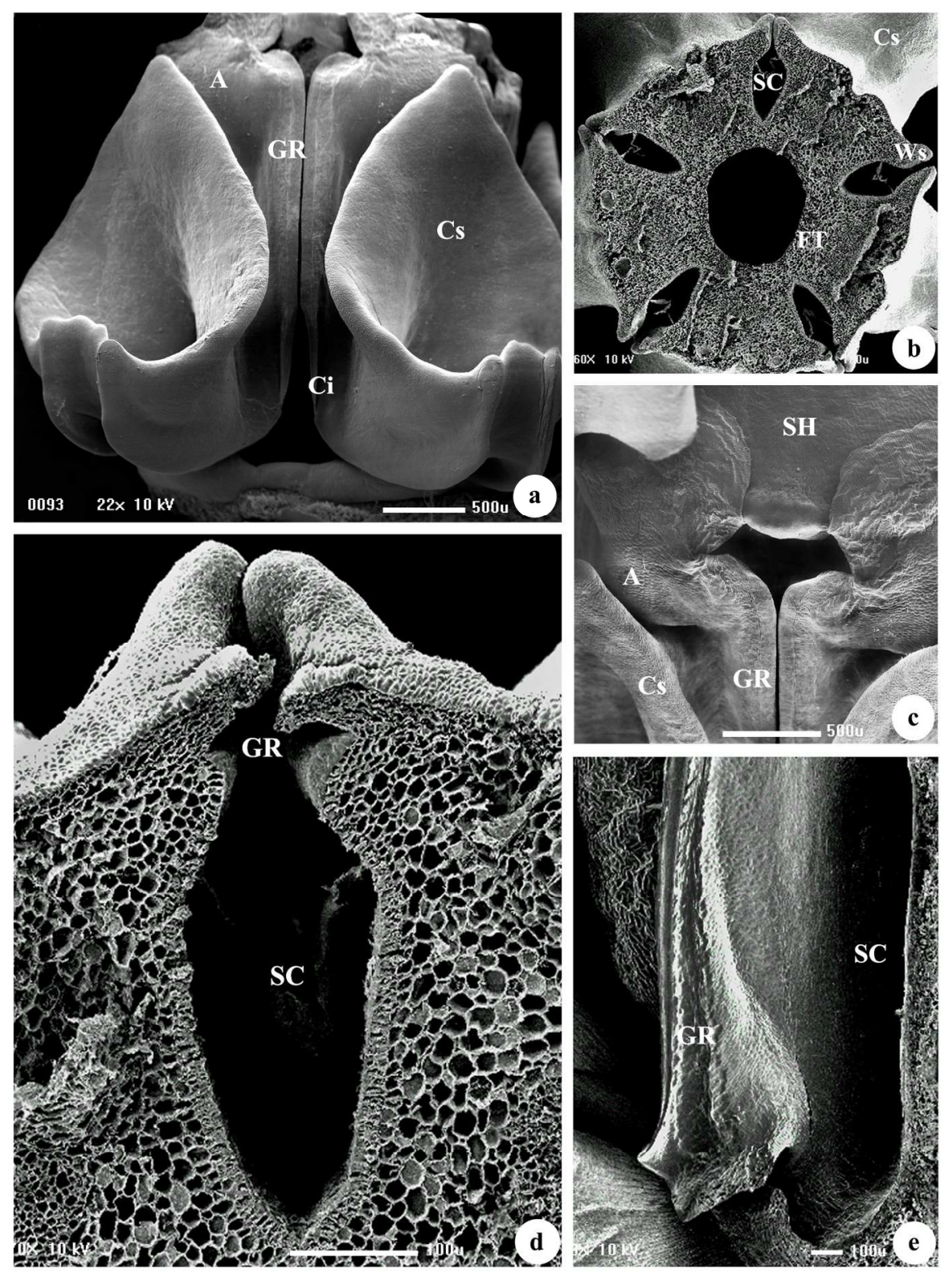

Figure 1

$152 \times 206 \mathrm{~mm}(300 \times 300$ DPI $)$ 


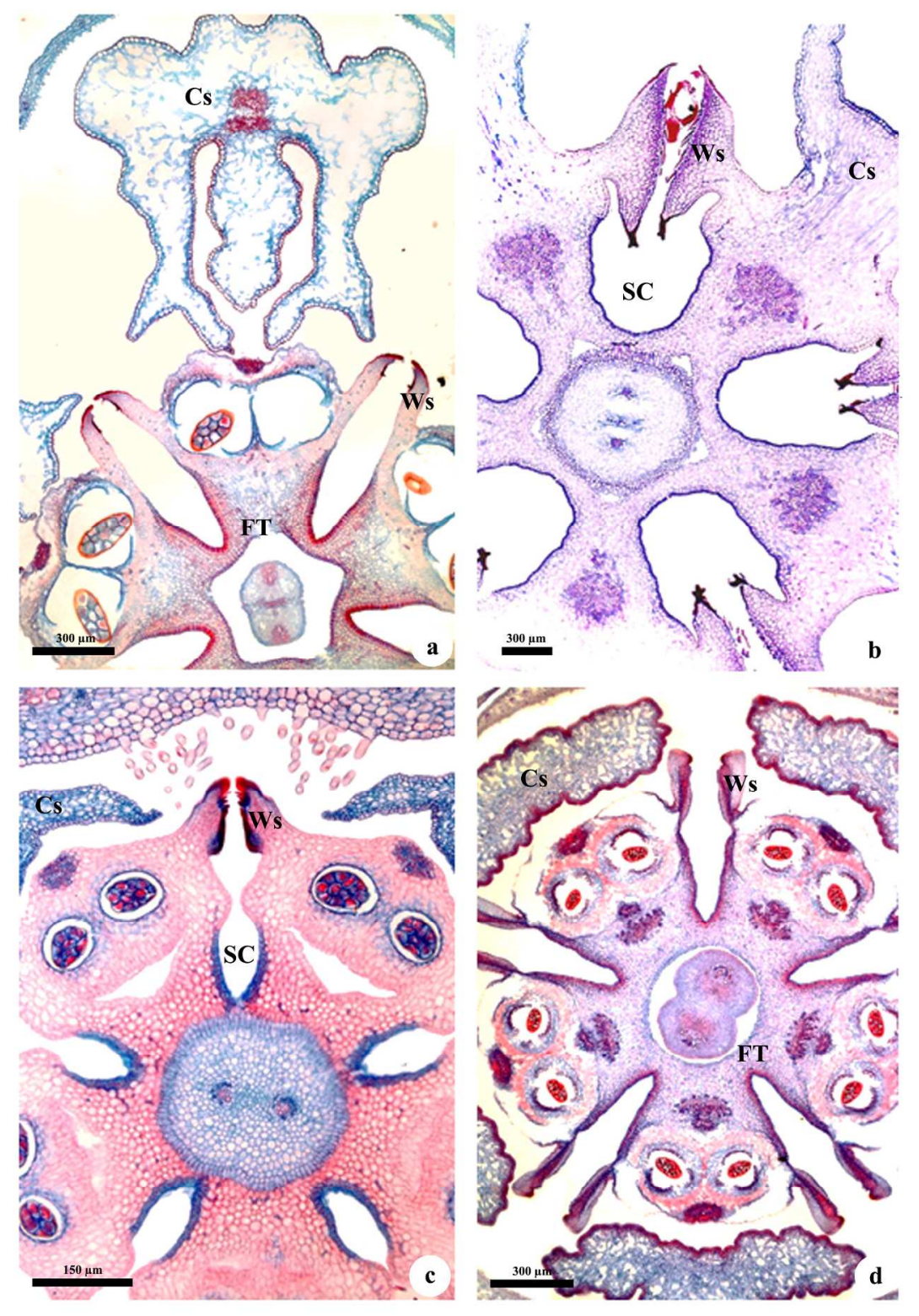

Figure 2

$155 \times 222 \mathrm{~mm}(300 \times 300 \mathrm{DPI})$ 


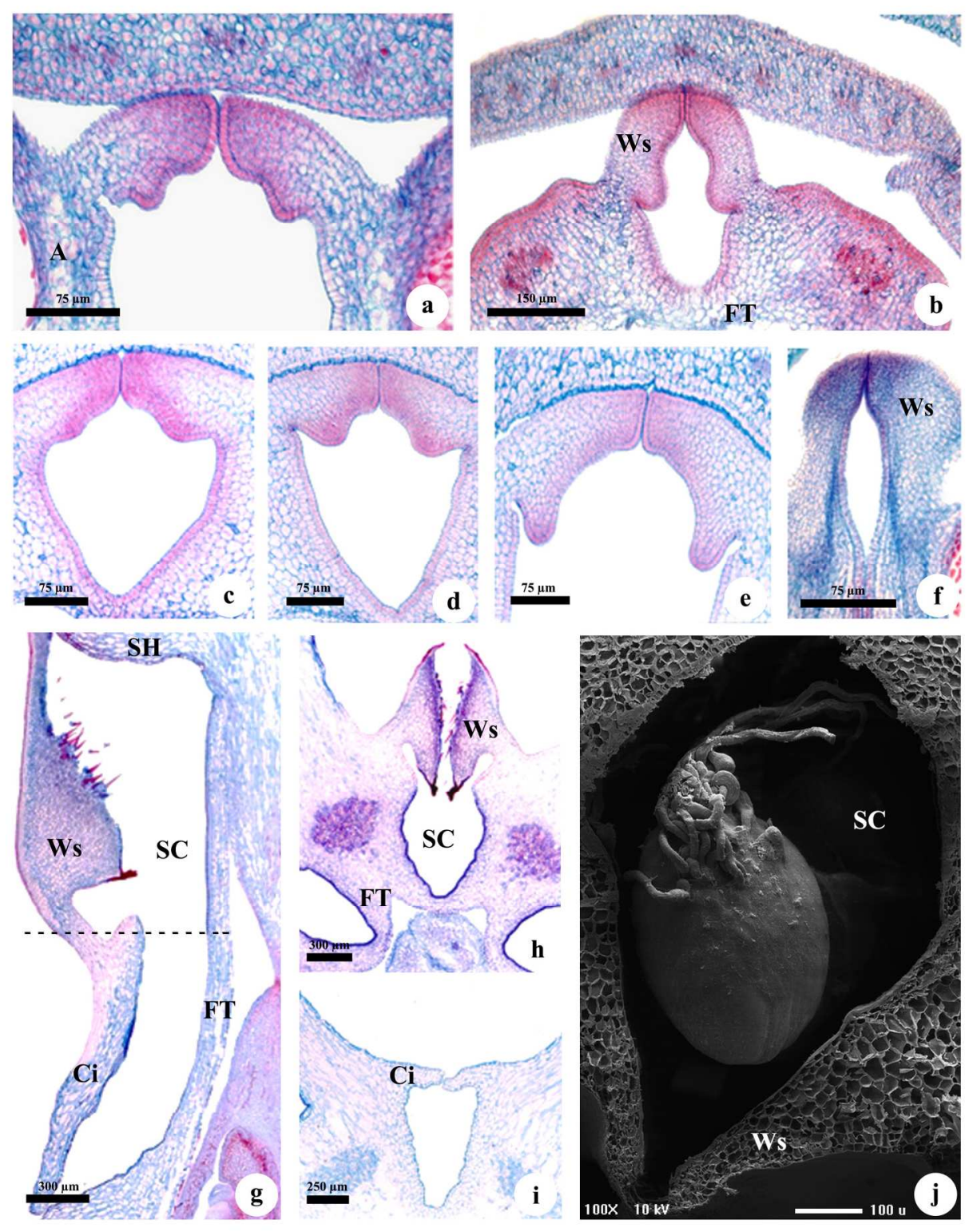

Figure 3

$161 \times 204 \mathrm{~mm}(300 \times 300$ DPI) 

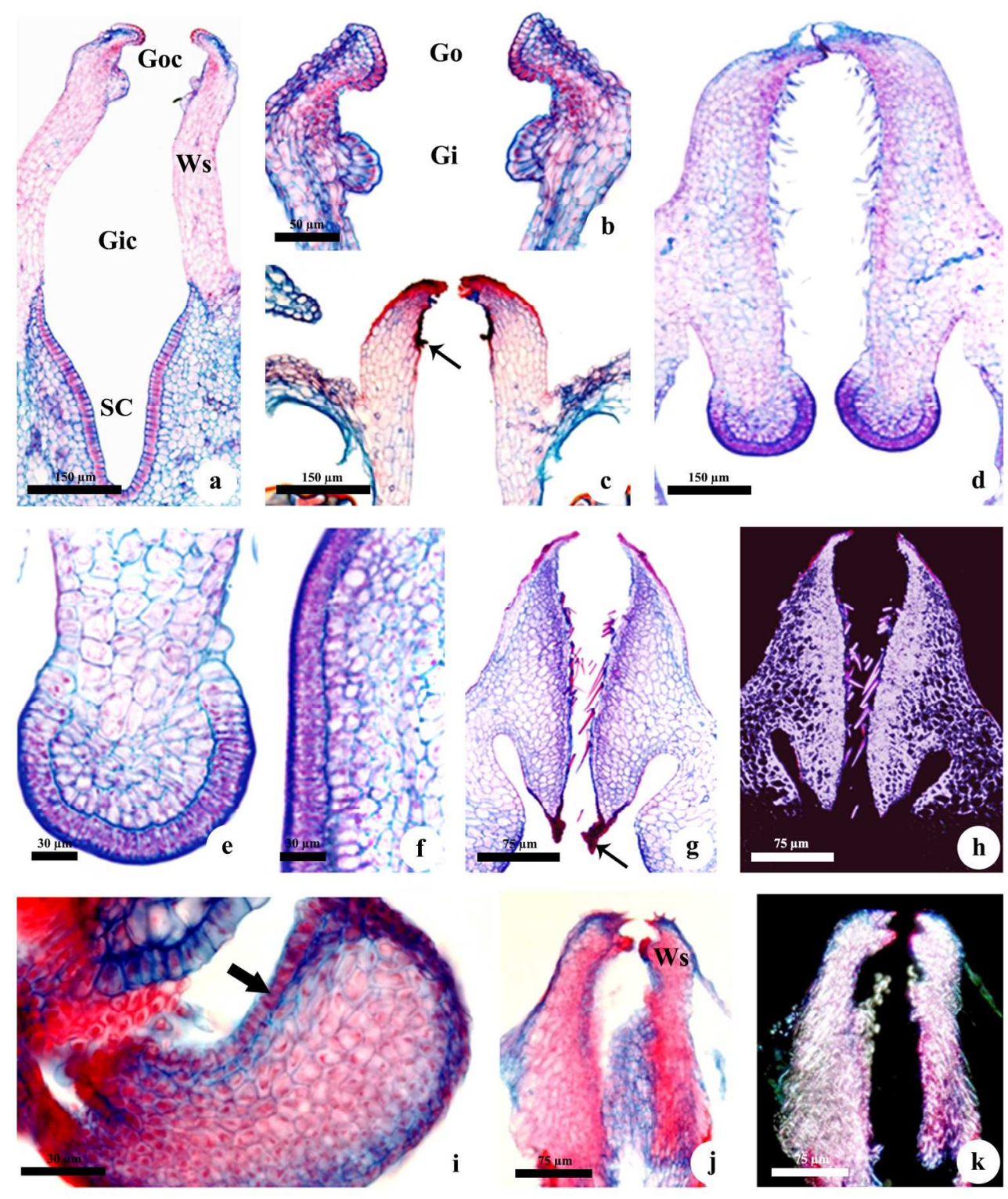

Figure 4

$165 \times 195 \mathrm{~mm}(300 \times 300$ DPI $)$ 

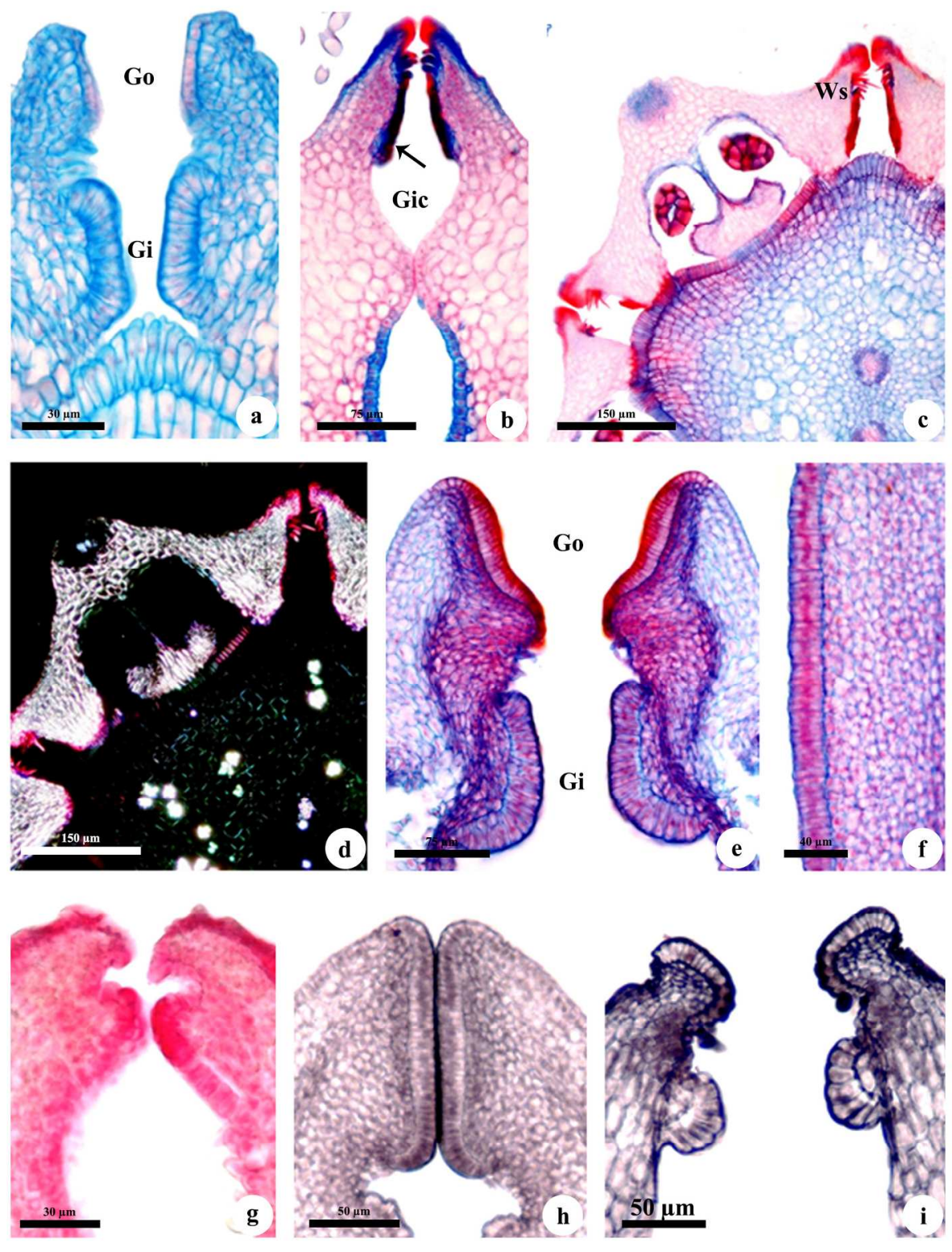

Figure 5

$166 \times 217 \mathrm{~mm}(300 \times 300 \mathrm{DPI})$ 